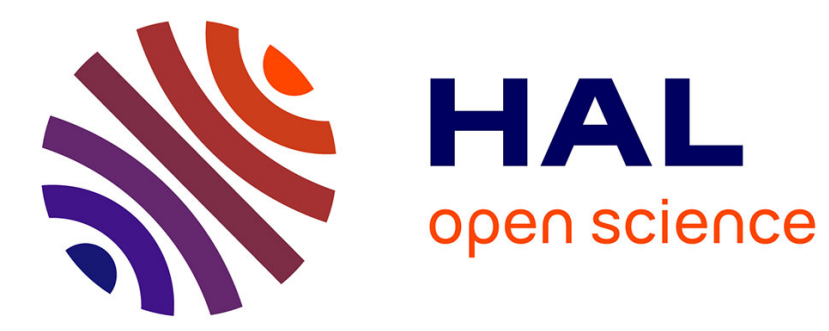

\title{
The autocrine and paracrine roles of adipokines
}

Kalypso Karastergiou, Vidya Mohamed-Ali

\section{To cite this version:}

Kalypso Karastergiou, Vidya Mohamed-Ali. The autocrine and paracrine roles of adipokines. Molecular and Cellular Endocrinology, 2010, 318 (1-2), pp.69. 10.1016/j.mce.2009.11.011 . hal-00567234

\section{HAL Id: hal-00567234 \\ https://hal.science/hal-00567234}

Submitted on 19 Feb 2011

HAL is a multi-disciplinary open access archive for the deposit and dissemination of scientific research documents, whether they are published or not. The documents may come from teaching and research institutions in France or abroad, or from public or private research centers.
L'archive ouverte pluridisciplinaire HAL, est destinée au dépôt et à la diffusion de documents scientifiques de niveau recherche, publiés ou non, émanant des établissements d'enseignement et de recherche français ou étrangers, des laboratoires publics ou privés. 


\section{Accepted Manuscript}

Title: The autocrine and paracrine roles of adipokines

Authors: Kalypso Karastergiou, Vidya Mohamed-Ali

PII:

DOI:

S0303-7207(09)00576-0

Reference: doi:10.1016/j.mce.2009.11.011

MCE 7375

To appear in: $\quad$ Molecular and Cellular Endocrinology

Received date: $\quad$ 25-9-2009

Revised date: $\quad 16-11-2009$

Accepted date: $\quad$ 23-11-2009

Please cite this article as: Karastergiou, K., Mohamed-Ali, V., The autocrine and paracrine roles of adipokines, Molecular and Cellular Endocrinology (2008), doi:10.1016/j.mce.2009.11.011

This is a PDF file of an unedited manuscript that has been accepted for publication. As a service to our customers we are providing this early version of the manuscript. The manuscript will undergo copyediting, typesetting, and review of the resulting proof before it is published in its final form. Please note that during the production process errors may be discovered which could affect the content, and all legal disclaimers that apply to the journal pertain. 
The autocrine and paracrine roles of adipokines

Kalypso Karastergiou ${ }^{1,2}$, Vidya Mohamed-Ali ${ }^{1}$

1 Adipokines and Metabolism Research Group, Centre for Clinical Pharmacology, Division of Medicine, University College London, London, UK

2 Department of Cardiac \& Vascular Sciences, St George's University of London, London, UK

\section{Address for Correspondence}

Vidya Mohamed-Ali

Adipokines and Metabolism Research Group

Centre for Clinical Pharmacology

Division of Medicine

University College London

5 University St, London

UK WC1 6JJ

Tel. +44 2076790968

Fax. +44 2076796211

E-mail: $\underline{\text { rmhavma@ucl.ac.uk }}$ 
Keywords. Adipokines, adipogenesis, lipolysis, obesity, adipose tissue, inflammation

\begin{abstract}
.
Obesity, defined by an excess of adipose tissue, is often associated with the development of various metabolic diseases. The increased and inappropriate deposition of this tissue contributes to hyperglycemia, hyperlipidemia, insulin resistance, endothelial dysfunction and chronic inflammation. Recent evidence suggests that factors expressed and secreted by the adipose tissue, adipokines, may contribute to the development of these abnormalities by mechanisms including inhibition of adipogenesis, adipocyte hypertrophy and death, immune cell infiltration and disruption of tissue metabolism. The presence of adipokine receptors in adipocytes renders these cells available to autocrine and paracrine effects of adipokines. In this review the reported local effects of adipokines on adipose tissue structure, inflammation and regulation of metabolic functions, in the face of over-nutrition and consequent obesity, are outlined. Elucidating the local regulation of white adipocyte development and function could help in the design of effective, tissue-specific therapies for obesity-associated diseases.
\end{abstract}

Introduction. Obesity, affected by the expanding adipose tissue mass, has necessitated the study and understanding of this organ. It is now accepted that the adipose tissue is an important, dynamic participant in regulating whole-body metabolism and is crucial for glucose and energy homeostasis (Rosen and Spiegelman, 2006). Various diseases are closely associated with increased adipose tissue mass, including type 2 diabetes, atherosclerosis, hypertension, osteoarthritis and certain cancers (Greenberg and Obin, 2006). Obesity-associated changes in the structure and function of adipose tissue and its distribution are affected by and effect changes in the adipokine secretory repertoire and profoundly influence the susceptibility of an individual to the associated pathologies (Björntorp, 1991).

Obesity has been described as a low grade inflammatory condition, with both the cellularity and the secretions of adipose tissue reflecting these changes. Current evidence suggests that over-nutrition leads to adipocyte hypertrophy, followed by cell death, which may act as a stimulus for immune cell infiltration into the tissue (Strissel et al., 2007; Murano et al., 2008). Monocyte infiltration and differentiation in particular has been shown to correlate with adipocyte hypertrophy, as well as body mass (Weisberg et al 2003). These macrophages, in response to the endocrine and metabolic milieu prevalent in the obese adipose tissue, switch their phenotype from one of a non-inflammatory resident macrophage to that of a lipid engorged foam cell, expressing dendritic cell markers, such as CD11c (Lumeng et al., 2007). The secretions of these macrophages, such as IL-6 and TNF $\alpha$, along with those from the hypertrophied adipocyte, such as MCP-1 and leptin, regulate the pathological changes of obesity, like insulin resistance and endothelial dysfunction (Figure 1). These autocrine/paracrine effects augment the endocrine changes mediated by the molecules in other organs such as liver, heart and skeletal muscle. All the signals released from or expressed by the adipose tissue are referred to as adipokines here, even though these include cytokines, chemokines and products of tissue enzyme activity (Table 1). 


\section{i) Adipokines, adipose tissue structure and regional distribution.}

Two histologically and functionally distinct types of adipose tissue have been identified: white (WAT) and brown adipose tissue (BAT). In mice, BAT exists throughout adulthood, while in humans it was thought to exist mainly in the neonatal period, having largely disappeared within the first years after birth. However, recent evidence suggests that adults retain metabolically active BAT depots that can be cold-induced and respond to sympathetic nervous system activation (Frühbeck et al., 2009).

While BAT is specialized in the production of heat and lipid oxidation, WAT functions as insulation, an exemplary store of excess energy as triacylglycerols, mediator of glucose homeostasis and an important endocrine/immune organ that secretes adipokines, that include inflammatory cytokines, chemokines, acute phase proteins and complementlike factors (Table 1 lists some of these). These adipokines may act as endocrine factors that regulate many central and peripheral processes, including appetite, energy metabolism, glucose and lipid metabolism, inflammatory responses, angiogenesis, blood pressure and reproductive function. The endocrine effects of adipokines have been extensively and expertly reviewed elsewhere (Halberg et al., 2008).

WAT is composed of many cell types, with about $50 \%$ of it being adipocytes, $10 \%$ resident macrophages and the rest comprising preadipocytes, endothelial and epithelial cells. Both the adipocytes and the non-adipocyte cells secrete adipokines. Adiponectin, and to a lesser extent, leptin, are largely adipocyte products, with signals such as MCP-1 and IL- 6 being produced by the hypertrophied fat cell and the non-fat cells producing many of the other inflammatory signals. In obesity, there is macrophage infiltration into WAT, with the number of these macrophages being directly correlated to adipocyte size (Cousin et al., 1999). In addition the phenotype of the macrophage is also altered to reflect a more inflammatory state (M1; Lumeng et al., 2007). It appears that these alterations in the cellularity of the tissue may lead to changes in local adipokines secretion and can potentially cause dysregulation of WAT-mediated disposal of dietary glucose and lipids, and in turn, contribute to hyperglycemia, hyperlipidemia, insulin resistance and chronic inflammation (Trayhurn, 2005).

Depot specific differences in adipose tissue secretory function are also dependent on the anatomical location of this tissue, which can accumulate in different compartments within the body. It is deposited peripherally in subcutaneous depots, such as mammary and gluteofemoral regions, and internally in visceral depots, as in the omental and epicardial regions. The expansion of these depots may occur both through adipocyte hypertrophy and hyperplasia. Accumulation of excess fat in the visceral compartment, even if subcutaneous fat mass is normal, carries the greater metabolic risk (Weyer et al., 2000; Wajchenberg, 2000; Smith et al., 2001). Insulin resistance, the precursor to type 2 diabetes, is closely associated to adipocyte hypertrophy in visceral, as opposed to subcutaneous, adipose tissue. It has been proposed that inhibition of adipogenesis, the process of conversion of pre-adipocytes to lipid-laden adipocytes, in subcutaneous depots, in the face of a continuing ability to differentiate visceral adipocytes normally, leads to type 2 diabetes (Danforth, 2000). This may be because the excess lipid that would have been stored in the subcutaneous depots is shunted to liver and skeletal muscle 
and results in impaired insulin action within these tissues and the development of peripheral insulin resistance (Smith et al., 2001).

Visceral depots also secrete more of the proinflammatory cytokines, such as IL-6, visfatin and MCP-1 (Greenberg and Obin, 2006, Madani, et al., 2009), which may be responsible for the insulin resistance. Conversely, in comparison with visceral adipose tissue, the subcutaneous depots appear less metabolically active and secrete more leptin and less free fatty acids (Wajchenberg, 2000). Therefore, excessive accumulation of subcutaneous adipose tissue is more likely to be associated with hyperleptinemia and may lead to central leptin resistance and greater susceptibility to further weight gain (Wajchenberg, 2000; Smith et al., 2001). Thus it is apparent that differential regional deposition of adipose tissue can impact on disease outcome, perhaps mediated by their altered adipokine repertoire.

\section{ii) Adipokine receptors and signal transduction.}

The presence of several of the adipokine receptors in adipocytes from both subcutaneous and visceral depots potentially renders these cells available to autocrine/paracrine regulation by adipokines. It has been demonstrated that human adipocytes express leptin receptors, both the long form (huOb-R), as well as the short forms B219.1 to B219.3 (Kielar et al., 1998, Apran-Husmann et al., 2001). The IL-6 receptor, together with the signal-transducing gp130 unit, is also present in isolated mature human adipocytes, as well as in those differentiated in vitro (Päth et al., 2001). The two TNF $\alpha$ receptors, (TNFR1 and TNFR2) are ubiquitously expressed, and interestingly, the expression of TNFR2 in human adipose tissue is positively correlated with BMI (Hotamisligil et al., 1997). Similarly, both adiponectin receptors are expressed (mRNA) in human adipose tissue and in isolated adipocytes from both subcutaneous and omental depots. Their levels correlate negatively with indices of obesity and metabolic dysfunction and are increased by physical exercise (Rasmussen et al., 2006, Nannipieri et al., 2007, Blüher et al., 2007). However, expression of the receptors is not proof of locally acting adipokines. Most of the evidence comes from in vitro studies that have used supra-physiological or pharmacological doses of these molecules to elicit a response. In the absence of tissue specific receptor knockout models or pharmacological inhibitors of the receptors local effects remains speculative.

In addition to the specific adipokine receptors, all toll-like receptors (TLRs 1-10, apart from 5 and 7) are expressed both in the stromavascular fraction and in mature adipocytes, from human subcutaneous and visceral adipose tissue (Kopp, 2009). These TLRs are essential innate immune receptors that classically alert the immune system to the presence of pathogens (Zhang and Schluesener, 2006). They recognize a large number of ligands, which includes LPS, zymosan and glycosylphosphotidylinositol lipid, and are capable of inducing the expression of a variety of inflammatory genes, like cytokines and chemokines. They can thus attract and activate T-cells in response to chemokines, such as RANTES. Their role in obesity or in response to excess energy intake is currently being investigated. 
The signalling pathways that are apparent in the adipocytes and can be activated by the adipokines include those most commonly implicated in inflammation such as the NFkB and JAK/STAT pathways (Table 2).

\section{iii) Adipokine regulation of adipose mass and blood flow.}

During adipogenesis, fibroblast-like preadipocytes differentiate into lipid-laden and insulin-responsive adipocytes. This process occurs in several stages and involves a cascade of transcription factors, among which peroxisome proliferator-activated receptor gamma (PPAR $\gamma)$ and CCAAT/enhancer-binding proteins (C/EBPs) are considered the crucial determinants of adipocyte fate. The involvement of additional factors, including Krupel-like factors (KLFs), Wingless and INT-1 proteins (Wnts), and cell-cycle proteins has also been reported (Lefterova and Lazar, 2009). Differentiation of fibroblast-like preadipocytes to mature adipocytes is a continuous process in adipose tissue. Although the number of total adipocytes in an individual is determined during childhood and adolescence, there is constant turnover and about $10 \%$ of all adipocytes are renewed per year at all adult ages and throughout the spectrum of BMI (Spalding et al., 2008). Several of the proinflammatory adipokines, such as TNFa, act as potent inhibitors of adipogenesis, possibly via inhibition of PPAR $\gamma$-dependent phenomena, as shown by the fact that thiazolidinediones prevent TNF $\alpha$-induced anti-adipogenesis (Cawthorn and Sethi, 2008). Furthermore, both in 3T3L1 (Cawthorn et al., 2007) and in human preadipocytes (Isakson et al., 2009), this TNF $\alpha$-effect is dependent on Wnt/ $\beta$-catenin/T-cell factor 4 pathway.

IL-6 (20 ng/ml) also inhibits differentiation and lipid accumulation of 3T3L1 fibroblasts. The main adipogenic transcription factor affected by IL-6 is $\mathrm{C} / \mathrm{EBP} \alpha$, whereas earlier activation of $\mathrm{C} / \mathrm{EBP} \delta, \mathrm{C} / \mathrm{EBP} \beta$ and PPAR $\gamma$ remain intact (Gustafson et al., 2006). Chemerin, acting via the relevant receptor in 3T3L1 and human preadipocytes also impairs PPAR $\gamma$ expression and cellular differentiation (Gorlaski et al., 2007, Roh et al., 2007). Interestingly, with all these adipokines, not only is adipogenesis is inhibited, but in addition, the cells acquire a more macrophage-like phenotype (Isakson et al., 2009) and express a number of inflammatory genes, like IL-6, MCP1 and PAI-1 (Gustafson et al., 2006, Gorlaski et al., 2007). Resistin had no clear effect on the in vitro differentiation of 3T3-L1 adipocytes (Kim et al., 2001, Gong et al., 2004), however, in vivo data from a transgenic mouse model support an inhibitory role of resistin in adipogenesis (Kim et al., 2004). The same appears to apply to PAI-1, as primary adipocytes from PAI-1 deficient mice show accelerated differentiation and overexpression of PAI-1 in 3T3L1 adipocytes suppressed CEBP $\alpha$ and PPAR $\gamma$ expression, and, subsequently differentiation (Liang et al., 2006).

Data on adipokines that may act as promoters of differentiation are scarce. In this context the effects of adiponectin on adipogenesis appear to be diverse. In brown pre-adipocytes derived from human bone marrow, adiponectin suppressed differentiation, via activation of COX-2 and increased PGE2 synthesis (Yokota et al., 2002). On the other hand, in 3T3L1 adipocytes adiponectin overexpression promoted preadipocyte proliferation and accelerated expression of adipogenic transcription factors and adipogenesis ( $\mathrm{Fu}$ et al., 2005). There are also some data that macrophage migration inhibitory factor (MIF), 
which is induced and released by adipocytes after treatment with TNF $\alpha$ (Hirokawa et al., 1997), might facilitate adipogenesis. Knocking down of MIF in 3T3L1 preadipocytes restricted their proliferation and suppressed expression of $\mathrm{C} / \mathrm{EBP} \delta$; as a result expression and activation of $\mathrm{C} / \mathrm{EBP} \alpha$ and PPAR $\gamma$ and cell differentiation were also inhibited (Ikeda et al., 2008).

The renin - angiotensin system (RAS) and the relevant receptors, $\mathrm{AT}_{1}$ and $\mathrm{AT}_{2}$, are expressed in adipose tissue (Engeli et al., 2000). The effects of the locally produced angiotensin II appear to be dependent on the balance between the expression of the two receptors. Thus, initial in vitro experiments suggested that angiotensin II promotes preadipocyte differentiation via the $\mathrm{AT}_{2}$ receptor (Engeli et al., 2000). Subsequently, however, it was shown that the in vivo effects of angiotensin II are mediated primarily via $\mathrm{AT}_{1}$ and in this case the end result is expansion of adipose tissue, primarily because of adipocyte hypertrophy, and thus metabolic dysfunction (Massiéra et al., 2001, Tomono et al., 2008).

While not truly adipokines, products of enzyme activity within the adipose tissue such as NEFA and the prostaglandins, also have documented, potent autocrine/paracrine effects on adipose tissue differentiation and metabolism (Frayn, 1998, Richelsen, 1992, Négrel, 1999). Prostacyclin especially has been shown to be an inducer of adipogenesis by activating both C/EBP and PPAR $\gamma$ (Vassaux et al., 1992).

The nitric oxide (NO) pathway has also come under some scrutiny as endothelial function, determined largely by bioavailability of NO, and insulin sensitivity, are both modulated by adiposity (Caballero, 2003, Ritchie et al., 2004). Although it has been postulated that adipokines, such as leptin, TNF $\alpha$ and IL-6, act on the endothelium to produce detrimental effects (Clarke and Mohamed-Ali, 2004), to date none has clearly been identified. NO is generated in adipose tissue and adipocytes (Ryden et al, 2001). While both eNOS, and to a lesser extent iNOS, are expressed in adipose tissue and adipocytes, only eNOS expression increases with obesity (Ryden et al., 2001). Asymmetric dimethylarginine (ADMA) is a novel risk factor for cardiovascular disease that inhibits nitric oxide (NO) bioavailability and causes endothelial dysfunction (Vallance and Leiper, 2002). ADMA is cleared by catabolism through the activity of dimethylarginine dimethylaminohydrolase (DDAH1 and 2; Vallance and Leiper, 2002). In obesity the ADMA generated may act as an autocrine and/or paracrine inhibitor of eNOS, thus potentially affecting several NO-mediated functions of the adipose tissue, such as local blood flow (Ardilouze et al., 2004), lipolysis (Gaudiot, 1998), glucose metabolism (Tanaka et al., 2003) and mitochondrial biogenesis (Nisoli et al., 2004).

The role of NO in energy expenditure, food intake and body weight gain has been explored recently in eNOS $^{-/-}$mice (Nisoli et al., 2003). In the lean state these animals show no significant differences to wild-type littermates. However, on a weight-gaining diet the $\mathrm{eNOS}^{-/-}$mice were significantly heavier, with this weight gain attributed to greater feed efficiency (described as weight gain per gram of food intake). Adipose tissue from these $\mathrm{eNOS}^{-/-}$animals also had less mitochondrial DNA and mitochondrial enzymes, COXIV and Cytc, suggesting lower mitochondrial biogenesis (Nisoli et al., 
2003).

Recent studies have looked at ADMA in human obesity and shown a close relationship between BMI and plasma levels of ADMA and the L-arg/ADMA ratio, independent of other metabolic risk factors (Eid et al., 2004). Overweight and obese subjects had significantly elevated ADMA levels and lower L-arg/ADMA ratio compared to lean or normal individuals. Enzymes responsible for the biosynthesis and degradation of ADMA are expressed in the human adipose tissue (Spoto et al., 2007). This study showed ADMA release from adipose tissue from two healthy patients and reported higher DDAH2 in visceral adipose tissue and higher DDAH1 in the subcutaneous depot (Spoto et al., 2007). Interestingly adiponectin has been shown to reduce ADMA accumulation in human cultured endothelial cells (Eid et al., 2007). Modulation of this pathway in the adipose tissue has not, as yet, been investigated, especially with reference to the adipokines.

\section{iv) Role of adipokines in inflammation.}

The secretory function of adipocytes can also be modulated by adipokines, as shown mainly in in vitro models. TNF $\alpha$ is known to suppress adiponectin production by adipocytes, while it induces a number of pro-inflammatory mediators like IL-6, MCP-1 and PAI-1 (Cawthorn and Sethi, 2008), primarily via activation of Foxo1 (Ito Y et al, 2009). Treatment of differentiated human adipocytes with $T N F \alpha$ also significantly decreased the expression of angiotensinogen and haptoglobin (Wang et al., 2005). With regards to leptin, TNF $\alpha$ is thought to stimulate release of a preformed pool of leptin by 3T3L1 adipocytes and by murine adipose tissue in vivo (Kirchgessner et al., 1997). On the other hand, in human adipose tissue explants, TNF $\alpha$ has a stimulatory effect on leptin expression and release only in the presence of dexamethasone (Trujillo et al., 2006). Finally, TNF $\alpha$ upregulates expression of apelin in 3T3F442A adipocytes, in murine and human adipose tissue and increases circulating levels of apelin in mice in vivo (Daviaud et al., 2006). Therefore, TNF $\alpha$ might mediate the increased apelin levels noted in obesity (Boucher et al., 2005).

IL-6 has similar effects to TNF $\alpha$ on adipokine regulation. Given that it suppresses expression of PPAR $\gamma$ in rat adipocytes (Tanaka et al., 1999), 3T3L1 and 3T3F442A adipocytes (Lagathu et al., 2003) and in human subcutaneous adipose tissue explants (Sopasakis et al., 2004), it is not surprising that IL-6 inhibits adiponectin expression and/or release (Fasshauer et al., 2003a, Sopasakis et al., 2004, Simons et al., 2007). Furthermore, IL-6 can induce PAI-1 (Rega et al., 2005), MCP-1 (Fasshauer et al., 2004), as well as its own expression and release (Fasshauer et al., 2003b, Lagathu et al., 2003). Finally, IL-6 acts as a negative regulator of visfatin expression in 3T3L1 adipocytes (Kralisch et al., 2005) and does not alter leptin release (Bruun et al., 2002). Release of pro-inflammatory cytokines, TNF $\alpha$ and IL-6, is also induced by resistin in isolated human subcutaneous adipocytes, an effect which is possibly mediated by the NFrB and JNK pathways (Kusminski et al., 2007). It has been proposed that leptin, at least in part, regulates its own release by adipose tissue, based on findings in mice deficient for the leptin receptor, which present with high circulating leptin levels (Zhang et al., 1997). Furthermore, leptin stimulates adiponectin and visfatin expression and release by 
adipocytes and murine adipose tissue, both ex vivo and in vivo (Delporte et al., 2004, Tan et al., 2009).

Adiponectin exerts anti-inflammatory effects on adipocytes, as in other cellular populations, primarily via inhibition of the NFKB pathway (Ajuwon et al., 2005). As a result, release of a number of pro-inflammatory cytokines by adipocytes is significantly suppressed (IL-6, IL-8, GROa, MCP-1) (Dietze-Schroeder et al., 2005, Ajuwon et al., 2005, Sell et al., 2006). These changes might be of particular pathophysiological significance, given that they are adequate to inhibit adipocyte-induced skeletal muscle insulin resistance (Dietze-Schroeder et al., 2005). Similar anti-inflammatory actions might be exerted by vaspin, which was able to induce expression of adiponectin, while inhibiting expression of leptin, resistin and TNF $\alpha$ in murine WAT (Hida et al., 2005). Finally, apelin administration resulted in increased circulating adiponectin and reduced leptin concentrations without changes in mRNA expression of these two adipokines in adipose tissue. It seems likely however, that these effects might be secondary to wholebody changes in adiposity and energy expenditure, rather than the primary apelin effect (Higuchi et al., 2007).

From these in vitro data it is reasonable to speculate that in obesity the inflammatory signals are amplified in the adipose tissue and perpetuate both the cellular and the secretory changes reported. However no concrete evidence is currently available to support this hypothesis.

In view of adipose tissue expansion in obesity, the ability to form new vessels to prevent adipocyte hypoxia, or the failure to do so, might be of particular importance (Trayhurn et al., 2008). Among the adipokines, leptin is known to promote angiogenesis in several experimental models (Sierra-Honigmann et al., 1998, Bouloumié et al., 1998). In adipose tissue it also induces angiostatic signals (angiopoietin-2) and tissue de-vascularization (Cohen et al., 2001). Adiponectin, by activating AMP kinase in endothelial cells, is also able to induce angiogenesis (Ouchi et al., 2004), as shown in adiponectin-deficient mice, which have impaired responses to ischemia (Shibata et al., 2004). IL-6 also has the potential to act as an angiogenic factor, by inducing release of VEGF, as has been reported in both human subcutaneous and visceral adipose tissue explants and in isolated adipocytes and preadipocytes (Rega et al., 2007). Adipose derived VEGF may also directly induce angiogenesis in the tissue (Vona-Davis and Rose, 2009). Apelin and HGF have also been shown to induce angiogenesis, both in human umbilical vein endothelial cells in vitro, and in adipose tissue in transplantation model in vivo. Interestingly, given that hypoxia induces its expression in 3T3F442A adipocytes, they may represent a compensatory mechanism of adipocytes against oxygen deprivation in obesity and other disease states (Kunduzova et al., 2008; Bell et al., 2008).

\section{v) Autocrine/paracrine regulation of glucose and lipid metabolism.}

Deposition of energy in adipose tissue occurs primarily via hydrolysis of circulating triglycerides by lipoprotein lipase (LPL), uptake of fatty acids and re-esterification to glycerol within the cell or via de novo lipogenesis. Interestingly, ASP is a potent stimulator of triglyceride synthesis in adipocytes in vitro (Baldo et al., 1993) and is 
released by adipose tissue in vivo in the postprandial period, when net fatty acid uptake by the tissue occurs (Saleh et al., 1998). TNFa has opposing effects on free fatty acid uptake by adipocytes, probably by interfering with the expression and activity of LPL and fatty acid binding and transport proteins (Cawthorn and Sethi, 2008). It has also been shown that IL-6 inhibits LPL activity in 3T3L1 adipocytes and in murine adipose tissue in vivo (Greenberg et al., 1992), whereas resistin increases LPL activity (Kim et al., 2007). In view of some of the opposing effects of these adipokines on fatty acid uptake and the lack of in vivo data it is difficult to speculate on their precise role in obesity.

In the face of negative energy balance, adipose tissue releases free fatty acids after intracellular hydrolysis of triglycerides by adipose triacylglycerol lipase (ATGL) and hormone-sensitive lipase (HSL). TNF $\alpha$ is a potent stimulator of lipolysis. At least two distinct mechanisms have been implicated: downregulation of perilipin, leading to exposure of the lipid droplet to the lipases, and suppression of the antilipolytic GTPbinding membrane proteins $\mathrm{Ga}_{\mathrm{i}}$ (Rydén and Arner, 2007). Leptin also induces lipolysis in mouse or rat adipocytes (Frühbeck et al., 1997). In human adipocytes, however, from either lean or obese healthy subjects, leptin treatment failed to modulate lipolysis (basal or isoprotenerol-stimulated or insulin-mediated anti-lipolysis), (Apran-Husmann et al., 2001, Elimam et al., 2002).

It has been reported that IL-6 increases basal, as well as isoprenaline-stimulated, lipolysis in 3T3L1 (Petersen et al., 2005) and in human mammary adipocytes (Päth et al., 2001); however, very high IL- 6 concentrations $(\geq 100 \mathrm{ng} / \mathrm{ml}$ ) were used in these experiments. Under physiological conditions, adipocytes are chronically exposed to IL-6 at the lower $\mathrm{ng} / \mathrm{ml}$ range, which however exceed circulating concentrations by orders of magnitude (Sopasakis et al., 2004). Finally, recent data indicate that chemerin acts as an inhibitor of both basal and stimulated lipolysis in 3T3L1 adipocytes, possibly via a reduction in intracellular cAMP levels (Gorlaski et al., 2007).

Insulin plays a central role in the regulation of adipocyte metabolism, by acting as a potent inhibitor of lipolysis, while stimulating glucose uptake and fatty acid reesterification. TNF $\alpha$ antagonises the effects of insulin on adipocytes in multiple levels (Cawthorn and Sethi, 2008, Rydén M and Arner P, 2007). Firstly, it reduces protein levels of GLUT-4, insulin receptor (IR) and insulin receptor substrate-1 (IRS-1) in adipocytes, possibly by suppressing PPAR $\gamma$ expression and activity. Secondly, it disrupts downstream insulin signaling by inhibiting tyrosine phosphorylation of IR and IRS-1. Finally, it increases the intracellular concentrations of diacylglycerols and ceramides, which then in turn, compromise insulin signaling further. Leptin also interferes with insulin signaling (Pérez et al., 2004, Kraus et al., 2002) and insulin-mediated glucose uptake (Kraus et al., 2002) in mouse or rat adipocytes. As was noted for lipolysis, these findings are not reflected in human adipocytes: in this case, leptin does not appear to affect basal glucose uptake, and there is controversy as to whether or not it inhibits insulin-induced glucose uptake (Zhang et al., 1999, Apran-Husmann et al., 2001) and insulin-induced lipogenesis (Elimam et al., 2002). The initial reports regarding IL-6 effects on glucose uptake by 3T3L1 adipocytes were contradictory (Stouthard et al., 1996, Huppertz et al., 1996). Subsequently, high concentrations of IL-6 ( $\geq 20 \mathrm{ng} / \mathrm{ml}$ ) were 
shown to suppress expression, both at mRNA and protein levels, of GLUT-4 and IRS-1 and thus to reduce glucose uptake. In contrast to TNF $\alpha$, IL-6 does not interfere with the phosphorylation of IR and IRS-1 (Rotter et al., 2003, Lagathu et al., 2003). Resistin seems to act as another inhibitor of glucose uptake in differentiated human subcutaneous preadipocytes and adipocytes, although its effects appear modest (McTernan et al., 2003). Insulin-sensitizing effects of other adipokines have also been reported. Overexpression of adiponectin in 3T3L1 adipocytes resulted in increased expression of GLUT4 and enhanced insulin-mediated glucose uptake (Fu et al., 2005); on the other hand, treatment of pig adipocytes with adiponectin (full-length and globular at $30 \mu \mathrm{g} / \mathrm{ml}$ ) inhibited insulin-mediated lipogenesis (Jacobi et al., 2004). Vaspin, a product of murine visceral adipose tissue, induced expression of GLUT-4 in WAT after in vivo administration and improved whole-body insulin sensitivity and glucose tolerance (Hida et al., 2005). Omentin, which is also preferentially expressed and release by visceral adipose tissue, appears to increase adipocyte insulin sensitivity and promote insulin-stimulated glucose uptake, via stimulation of Akt phosphorylation (Yang et al., 2006). Finally, chemerin promotes insulin-mediated IRS-1 phosphorylation and concomittantly enhances glucose uptake in 3T3L1 adipocytes (Takahashi et al., 2008).

In addition to studies on adipocytes, whole-body animal models can offer further insight in the function of adipokines. Thus, it has been suggested that leptin in vivo inhibits fat accumulation in adipose tissue. It is known that high circulating leptin levels in obesity are not effective in body weight regulation due to the accompanying leptin resistance. However, induction of hyperleptinemia in leptin-sensitive lean rats results in rapid depletion of fat stores. In addition, constitutive overexpression of the leptin receptor in adipose tissue, which overcomes leptin resistance, prevents high fat diet-induced obesity. At a molecular level, this is accompanied by induction of leptin signaling pathways (STAT-3), activation of AMPK and PCG-1 $\alpha$, and upregulation of UCP-1 and UCP-2 in WAT(Wang et al., 2005). Because of the failure of adipose tissue as an energy store, these mice show ectopic fat deposition and metabolic dysregulation (Wang et al., 2008).

Data from a transgenic model suggest that resistin impairs fatty acid re-esterification in the adipose tissue and thus leads to increased free fatty acid release and systemic insulin resistance (Pravenec et al., 2006).

Conclusion. There is accumulating evidence that in obesity, adipose tissue expands, through adipocyte hypertrophy that is facilitated by inhibition of adipogenesis and adipocyte death. These areas of cell death form focal points for macrophage infiltration into the tissue. The infiltrating macrophage switch from a non-inflammatory phenotype to form foam cells. Continued accumulation of body fat is accompanied by adipocyte hyperplasia and hypertrophy, along with further increases in macrophage numbers. All stages of this process are accompanied by changes in, and are mediated by, autocrine and paracrine effects of adipokines on adipogenesis, angiogenesis, inflammation and adipocyte metabolism. Many of these effects may impact on the development of endothelial dysfunction and insulin resistance, important precursors of various metabolic diseases, such as atherosclerosis and type 2 diabetes. Understanding the putative role of these molecules in shifting the adipocytes from the large, insulin-resistant to the small, insulin-responsive phenotypes, may constitute an attractive strategy for treating metabolic 
disease. Targeted induction of specific adipokines may facilitate such a shift in adipose tissue cellularity as well as in adipocyte morphology and function. Thus, elucidating the mechanisms underlying WAT secretory function and the ability to modulate this may, in future, be important in treating the pathological consequences of obesity. 


\section{Acknowledgements.}

Aspects of this work were funded by grants from Heart Research UK (RG 2580/09/11), European Commission (EXGENESIS: LSHM-CT-2004-005272) and The Wellcome Trust (Grant number GR078055MA). 


\section{References:}

Ajuwon, K.M., Spurlock, M.E., 2005. Adiponectin inhibits LPS-induced NF-кB activation and IL- 6 production and increases PPAR $\gamma 2$ expression in adipocytes. Am. J. Physiol. Regul. Integr. Comp. Physiol. 288, R1220-R1225.

Alessi, M. C., Peiretti, F., Morange, P., Henry, M., Nalbone, G., Juhan-Vague, I., 1997. Production of plasminogen activator inhibitor 1 by human adipose tissue: possible link between visceral fat accumulation and vascular disease. Diabetes. 46, 860-867.

Apran-Husmann, I., Röhrig, K., Gottschling-Zeller, H., Skurk, T., Scriba, D., Birgel, M., Hauner, H., 2001. Effects of leptin on the differentiation and metabolism of human adipocytes. Int. J. Obes. Relat. Metab. Disord. 25, 1465-1470.

Ardilouze, J.L., Fielding, B.A., Currie, J.M., Frayn, K.N, Karpe F. 2004. Nitric oxide and beta-adrenergic stimulation are major regulators of preprandial and postprandial subcutaneous adipose tissue blood flow in humans. Circulation. 109, 47-52.

Baldo, A., Sniderman, A.D., St-Luce, S., Avramoglu, R.K., Maslowska, M., Hoang, B., Monge, J.C., Bell, A., Mulay, S. Cianflone, K., 1993. The adipsin-acylation stimulating protein system and regulation of intracellular triglyceride synthesis. J. Clin. Invest. 92, 1543-1547.

Bell, L.N., Cai, L., Johnstone, B.H., Traktuev, D.O., March, K.L., Considine, R.V., 2008. A central role for hepatocyte growth factor in adipose tissue angiogenesis. Am. J. Physiol. Endocrinol. Metab. 294, E336-E344.

Benditt, E.P., Meek, R.L., 1989. Expression of the third member of the serum amyloid A gene family in mouse adipocytes. J. Exp. Med. 169, 1841-1846.

Björntorp, P., 1991. Adipose tissue distribution and function. Int. J. Obes. 15, 67-81.

Blüher, M., Williams, C.J., Klöting, N., His, A., Ruschke, K., Oberbach, A., Fasshauer, M., Berndt, J., Schön, M.R., Wolk, A., Stumvoll, M., Mantzoros, C.S., 2007. Gene expression of adiponectin receptors in human visceral and subcutaneous adipose tissue is related to insulin resistance and metabolic parameters and is altered in response to physical training. Diabetes. Care. 30, 3110-3115.

Bouloumié, A., Drexler, H.C., Lafontan, M., Busse, R., 1998. Leptin, the product of Ob gene, promotes angiogenesis. Circ. Res. 83, 1059-1066.

Boucher, J., Masri, B., Daviaud, D., Gesta, S., Guigné, C., Mazzucotelli, A., CastanLaurell, I., Tack, I., Knibiehler, B., Carpéné, C., Audigier, Y., Saulnier-Blache, J.S., Valet, P., 2005. Apelin, a newly identified adipokine up-regulated by insulin and obesity. Endocrinology. 146, 1764-1771. 
Brake, D. K., Smith, E. O., Mersmann, H., Smith, C. W., Robker, R. L., 2006. ICAM-1 expression in adipose tissue: effects of diet-induced obesity in mice. Am. J. Physiol Cell Physiol. 291, C1232-C1239.

Bruun, J.M., Pedersen, S.B., Kristensen, K., Richelsen, B., 2002. Effects of proinflammatory cytokines and chemokines on leptin production in human adipose tissue in vitro. Mol. Cell. Endocrinol. 190, 91-99.

Bruun, J.M., Pedersen, S.B., Richelsen, B., 2001. Regulation of interleukin 8 production and gene expression in human adipose tissue in vitro. Journal of Clinical Endocrinology and Metabolism. 86, 1267-1273.

Caballero, A.,E., 2003. Endothelial dysfunction in obesity and insulin resistance: a road to diabetes and heart disease. Obes Res. 11, 1278-89.

Cawthorn, W.P., Heyd, F., Hegyi, K., Sethi, J.K., 2007. Tumour necrosis factor-alpha inhibits adipogenesis via a beta-catenin/TCF4(TCF7L2)-dependent pathway. Cell. Death. Differ. 14, 1361-1373.

Cawthorn, W.P., Sethi, J.K., 2008. TNF $\alpha$ and adipocyte biology. FEBS. Lett. 582, 117131.

Choy L., Derynck R., 2003. Transforming growth factor-beta inhibits adipocyte differentiation by Smad3 interacting with CCAAT/enhancer-binding protein (C/EBP) and repressing C/EBP transactivation function. J. Biol. Chem. 278, 9609-9619.

Cianflone, K. M., Sniderman, A. D., Walsh, M. J., Vu, H., Gagnon, J., Rodriguez, M. A., 1989. Purification and characterization of acyletion stimulating protein. J. Biol. Chem. 264, 426-430.

Claffey, K. P., Wilkison, W. O., Spiegelman, B. M., 1992. Vascular endothelial growth factor. Regulation by cell differentiation and activated second messenger pathways. J. Biol. Chem. 267, 16317-16322.

Clarke, D.K., Mohamed-Ali, V., 2004. Adipokines and Insulin Resistance. In Insulin Resistance: Insulin Action and its Disturbances in Disease. Eds. Stephen O'Rahilly and Sudesh Kumar, John Wiley \& Sons. 269-295.

Cohen, B., Barkan, D., Levy, Y., Goldberg, I., Fridman, E., Kopolovic, J., Rubinstein, M., 2001. Leptin induces angiopoietin-2 expression in adipose tissues. J. Biol. Chem. 276, 7697-7700.

Cook, K.S., Min, H.Y., Johnson, D., Chaplinsky, R.J., Flier, J.S., Hunt, C.R., Spiegelman, B.M., 1987. Adipsin: a circulating serine protease homolog secreted by adipose tissue and sciatic nerve. Science. 237, 402-405. 
Danforth, E.,Jr, 2000. Failure of adipocyte differentiation causes type II diabetes mellitus? Nat. Genet. 26, 13.

Daviaud, D., Boucher, J., Gesta, S., Dray, C., Guigne, C., Quilliot, D., Ayav, A., Ziegler, O., Carpene, C., Saulnier-Blache, J., Valet, P., Castan-Laurell, I., 2006. TNFalpha upregulates apelin expression in human and mouse adipose tissue. FASEB J. 20, 15281530.

Delporte, M.L., El Mkadem, S.A., Quisquater, M., Brichard, S.M., 2004. Leptin treatment markedly increased plasma adiponectin but barely decreased plasma resistin of ob/ob mice. Am. J. Physiol. Endocrinol. Metab. 287, E446-E453.

Dietze-Schroeder, D., Sell, H., Uhlig, M., Koenen, M., Eckel, J., 2005. Autocrine action of adiponectin on human fat cells prevents the release of insulin resistance-inducing factors. Diabetes. 54, 2003-2011.

Eid, H.M., Arnese, H., Hjerkinn, E.M., Lyberg, T., Seljeflot, I., 2004. Relationship Between Obesity, Smoking, and the Endogenous Nitric Oxide Synthase Inhibitor, Asymmetric Dimethylarginine. Metabolism. 53, 1574-1579.

Eid, H.M., Lyberg, T., Arnesen, H., Seljeflot, I., 2007. Insulin and adiponectin inhibit the TNFalpha-induced ADMA accumulation in human endothelial cells: the role of DDAH. Atherosclerosis. 194, e1-8.

Elimam, A., Kamel, A., Marcus, C., 2002. In vitro effects of leptin on human adipocyte metabolism. Horm. Res. 58, 88-93.

Engeli, S., Negrel, R., Sharma, A.M., 2000. Physiology and pathophysiology of the adipose tissue renin-angiotensin system. Hypertension. 35; 1270-1277.

Engelman J.A., Berg A.H., Lewis R.Y., Lisanti M.P., Scherer P.E., 2000. Tumor necrosis factor alpha-mediated insulin resistance, but not dedifferentiation, is abrogated by MEK1/2 inhibitors in 3T3-L1 adipocytes. Mol. Endocrinol. 14, 1557-69.

Fain J.N., Madan A.K., Hiler M.L., Cheema P., Bahouth S.W., 2004. Comparison of the release of adipokines by adipose tissue, adipose tissue matrix, and adipocytes from visceral and subcutaneous abdominal adipose tissues of obese humans. Endocrinology. $145,2273-2282$.

Fain, J.N., Nesbit, A.S., Sudlow, F.F., Cheema, P., Peeples, J.M., Madan, A.K., Tichansky, D.S., 2007. Release in vitro of adipsin, vascular cell adhesion molecule 1, angiotensin 1-converting enzyme, and soluble tumor necrosis factor receptor 2 by human omental adipose tissue as well as by the nonfat cells and adipocytes. Metabolism. 56, 1583-1590.

Farmer, S.R., 2008. Molecular determinants of brown adipocyte formation and function, Genes Dev. 22, 1269-1275. 
Fasshauer, M., Kralisch, S., Klier, M., Lossner, U., Bluher, M., Klein, J., Paschke, R., 2003. Adiponectin gene expression and secretion is inhibited by interleukin-6 in 3T3-L1 adipocytes. Biochem. Biophys. Res. Commun. 301, 1045-1050.

Fasshauer, M., Klein, J., Lossner, U., Paschke, R., 2003. Interleukin (IL)-6 mRNA expression is stimulated by insulin, isoproterenol, tumour necrosis factor alpha, growth hormone, and IL-6 in 3T3-L1 adipocytes. Horm. Metab. Res. 35, 147-152.

Fasshauer, M., Klein, J., Kralisch, S., Klier, M., Lossner, U., Bluher, M., Paschke, R., 2004. Monocyte chemoattractant protein 1 expression is stimulated by growth hormone and interleukin-6 in 3T3-L1 adipocytes. Biochem. Biophys. Res. Commun. 317, 598-604.

Fernández-Veledo S., Vila-Bedmar R., Nieto-Vazquez I., Lorenzo M., 2009. c-Jun Nterminal kinase $1 / 2$ activation by tumor necrosis factor-alpha induces insulin resistance in human visceral but not subcutaneous adipocytes: reversal by liver X receptor agonists. J. Clin. Endocrinol. Metab. 94, 3583-3593.

Fu, Y., Luo, N., Klein, R.L., Garvey, W.T., 2005. Adiponectin promotes adipocyte differentiation, insulin sensitivity, and lipid accumulation. J. Lipid. Res. 46, 1369-1379.

Frayn, K.N., 1998. Non-esterified fatty acid metabolism and postprandial lipaemia. Atherosclerosis. 141, S41-6.

Frederich, R.C., Kahn, B.B., Peach, M.J., Flier, J.S., 1992. Tissue-specific nutritional regulation of angiotensinogen in adipose tissue. Hypertension. 19, 339-344.

Friedrichs, W.E., Navarijo-Ashbaugh, A.L., Bowman, B.H., Yang, F., 1995. Expression and inflammatory regulation of haptoglobin gene in adipocytes. Biochem. Biophys. Res. Commun. 209, 250-256.

Frühbeck, G., Aguado, M., Martínez, J.A., 1997. In vitro lipolytic effect of leptin on mouse adipocytes: evidence for a possible autocrine/paracrine role of leptin. Biochem. Biophys. Res. Commun. 240, 590-594.

Frühbeck, G., Becerril, S., Sáinz, N., Garrastachu, P., García-Velloso, M.J., 2009. BAT: a new target for human obesity? Trends. Pharmacol. Sci. 30, 387-396.

Fukuhara, A., Matsuda, M., Nishizawa, M., Segawa, K., Tanaka, M., Kishimoto, K., Matsuki, Y., Murakami, M., Ichisaka, T., Murakami, H., Watanabe, E., Takagi, T., Akiyoshi, M., Ohtsubo, T., Kihara, S., Yamashita, S., Makishima, M., Funahashi, T., Yamanaka, S., Hiramatsu, R., Matsuzawa, Y., Shimomura, I., 2005. Visfatin: a protein secreted by visceral fat that mimics the effects of insulin. Science. 307, 426-430.

Gálvez, B.G., San Martín, N., Rodríguez, C., 2009. TNF-alpha is required for the attraction of mesenchymal precursors to WATin Ob/ob mice. PLoS. One. 4, e4444. 
Gao Z., Zuberi A., Quon M.J., Dong Z., Ye J., 2003. Aspirin inhibits serine phosphorylation of insulin receptor substrate 1 in tumor necrosis factor-treated cells through targeting multiple serine kinases. J. Biol. Chem. 278, 24944-24950.

Gaudiot, N., Jaubert, A.M., Charbonnier, E., Sabourault, D., Lacasa, D., Giudicelli, Y., Ribiere C., 1998. Modulation of WATlipolysis by nitric oxide. J. Biol. Chem. 273, 13475-13481.

Gerhardt, C.C., Romero, I.A., Cancello, R., Camoin, L., Strosberg, A.D., 2001. Chemokines control fat accumulation and leptin secretion by cultured human adipocytes. Molecular and Cellular Endocrinology. 175, 81-92.

Gong, H., Ni, Y., Guo, X., Fei, L., Pan, X., Guo, M., Chen, R., 2004. Resistin promotes 3T3-L1 preadipocyte differentiation. Eur. J. Endocrinol. 150, 885-892.

Goralski, K.B., McCarthy, T.C., Hanniman, E.A., Zabel, B.A., Butcher, E.C., Parlee, S.D., Muruganandan, S., Sinal, C.J., 2007. Chemerin, a novel adipokine that regulates adipogenesis and adipocyte metabolism. J. Biol. Chem. 282, 28175-28188.

Greenberg, A.S., Nordan, R.P., McIntosh, J., Calvo, J.C., Scow, R.O., Jablons, D., 1992. Interleukin 6 reduces lipoprotein lipase activity in adipose tissue of mice in vivo and in 3T3-L1 adipocytes: a possible role for interleukin 6 in cancer cachexia. Cancer. Res. 52, 4113-4116.

Greenberg, A.S., Obin, M.S., 2006.Obesity and the role of adipose tissue in inflammation and metabolism. Am. J. Clin. Nutr. 83, 461S-465S.

Guilherme A., Tesz G.J., Guntur K.V., Czech M.P., 2009. Tumor necrosis factor-alpha induces caspase-mediated cleavage of peroxisome proliferator-activated receptor gamma in adipocytes. J. Biol. Chem. 284, 17082-17091.

Gustafson, B., Smith, U., 2006. Cytokines promote Wnt signaling and inflammation and impair the normal differentiation and lipid accumulation in 3T3-L1 preadipocytes. J. Biol. Chem. 281, 9507-9516.

Halberg, N., Wernstedt-Asterholm, I., Scherer, P.E., 2008. The adipocyte as an endocrine cell. Endocrinol. Metab. Clin. North. Am. 37, 753-768.

Hida, K., Wada, J., Eguchi, J., Zhang, H., Baba, M., Seida, A., Hashimoto, I., Okada, T., Yasuhara, A., Nakatsuka, A., Shikata, K., Hourai, S., Futami, J., Watanabe, E., Matsuki, Y., Hiramatsu, R., Akagi, S., Makino, H., Kanwar, Y.S., 2005. Visceral adipose tissuederived serine protease inhibitor: A unique insulin-sensitizing adipocytokine in obesity. Proc. Natl. Acad. Sci. U S A. 102, 10610-10615.

Higuchi, K., Masaki, T., Gotoh, K., Chiba, S., Katsuragi, I., Tanaka, K., Kakuma, T., Yoshimatsu, H., 2007. Apelin, an APJ receptor ligand, regulates body adiposity and 
favors the messenger ribonucleic acid expression of uncoupling proteins in mice. Endocrinology. 148, 2690-2697.

Hirokawa, J., Sakaue, S., Tagami, S., Kawakami, Y., Sakai, M., Nishi, S., Nishihira, J., 1997. Identification of macrophage migration inhibitory factor in adipose tissue and its induction by tumor necrosis factor-alpha. Biochem. Biophys. Res. Commun. 235, 94-98.

Hotamisligil, G.S., Arner, P., Atkinson, R.L., Spiegelman, B.M., 1997. Differential regulation of the p80 tumor necrosis factor receptor in human obesity and insulin resistance. Diabetes. 46, 451-455.

Hotamisligil, G. S., Shargill, N. S., Spiegelman, B. M., 1993. Adipose expression of tumor necrosis factor-alpha: direct role in obesity-linked insulin resistance. Science. 259, 87-91.

Hu, E., Liang, P., Spiegelman, B. M., 1996. AdipoQ is a novel adipose-specific gene dysregulated in obesity. J. Biol. Chem. 271, 10697-10703.

Huppertz, C., Schwartz, C., Becker, W., Horn, F., Heinrich, P.C., Joost, H.G., 1996. Comparison of the effects of insulin, PDGF, interleukin-6, and interferon-gamma on glucose transport in 3T3-L1 cells: lack of cross-talk between tyrosine kinase receptors and JAK/STAT pathways. Diabetologia. 39, 1432-1439.

Ikeda, D., Sakaue, S., Kamigaki, M., Ohira, H., Itoh, N., Ohtsuka, Y., Tsujino, I., Nishimura, M., 2008. Knockdown of Macrophage Migration Inhibitory Factor

Disrupts Adipogenesis in 3T3-L1 Cells. Endocrinology. 149, 6037-6042.

Isakson, P., Hammarstedt, A., Gustafson, B., Smith, U., 2009. Impaired Preadipocyte Differentiation in Human Abdominal Obesity. Diabetes. 58, 1550-1557.

Ito, Y., Daitoku, H., Fukamizu, A., 2009. Foxo1 increases pro-inflammatory gene expression by inducing $\mathrm{C} / \mathrm{EBPb}$ in TNF-a-treated adipocytes. Biochem. Biophys. Res. Commun. 378, 290-295.

Iwata M., Haruta T., Usui I., Takata Y., Takano A., Uno T., Kawahara J., Ueno E., Sasaoka T., Ishibashi O., Kobayashi M., 2001. Pioglitazone ameliorates tumor necrosis factor-alpha-induced insulin resistance by a mechanism independent of adipogenic activity of peroxisome proliferator--activated receptor-gamma. Diabetes. 50, 1083-1092.

Jacobi, S.K., Ajuwon, K.M., Weber, T.E., Kuske, J.L., Dyer, C.J., Spurlock, M.E., 2004. Cloning and expression of porcine adiponectin, and its relationship to adiposity, lipogenesis and the acute phase response. J. Endocrinol. 182, 133-144.

Juge-Aubry, C.E., Somm, E., Pernin, A., Alizadeh, N., Giusti, V., Dayer, J.M., Meier, C.A., 2005. Adipose tissue is a regulated source of interleukin-10. Cytokine. 29, 270-274. 
Kielar, D., Clark, J.S., Ciechanowicz, A., Kurzawski, G., Sulikowski, T., Naruszewicz, M., 1998. Leptin receptor isoforms expressed in human adipose tissue. Metabolism. 47, 844-847.

Kim, K.H., Lee, K., Moon, Y.S., Sul, H.S., 2001. A cysteine-rich adipose tissue-specific secretory factor inhibits adipocyte differentiation. J. Biol. Chem. 276, 11252-11256.

Kim, K.H., Zhao, L., Moon, Y., Kang, C., Sul, H.S., 2004. Dominant inhibitory adipocyte-specific secretory factor (ADSF)/resistin enhances adipogenesis and improves insulin sensitivity. Proc. Natl. Acad. Sci. U S A. 101, 6780-6785.

Kim K.Y., Kim J.K., Jeon J.H., Yoon S.R., Choi I., Yang Y., 2005. c-Jun N-terminal kinase is involved in the suppression of adiponectin expression by TNF-alpha in 3T3-L1 adipocytes. Biochem. Biophys. Res. Commun. 327, 460-467.

Kim, S.J., Nian, C., McIntosh, C.H., 2007. Resistin is a key mediator of glucosedependent insulinotropic polypeptide (GIP) stimulation of lipoprotein lipase (LPL) activity in adipocytes. J. Biol. Chem. 282, 34139-34147.

Kirchgessner, T.G., Uysal, K.T., Wiesbrock, S.M., Marino, M.W., Hotamisligil, G.S., 1997. Tumor necrosis factor-alpha contributes to obesity-related hyperleptinemia by regulating leptin release from adipocytes. J. Clin. Invest. 100, 2777-2782.

Kita A., Yamasaki H., Kuwahara H., Moriuchi A., Fukushima K., Kobayashi M., Fukushima T., Takahashi R., Abiru N., Uotani S., Kawasaki E., Eguchi K., 2005. Identification of the promoter region required for human adiponectin gene transcription: Association with CCAAT/enhancer binding protein-beta and tumor necrosis factor-alpha. Biochem. Biophys. Res. Commun. 331, 484-490.

Klein, S., Coppack, S.W., Mohamed-Ali, V., Landt, M., 1996. Adipose tissue leptin production and plasma leptin kinetics in humans. Diabetes. 45, 984-987.

Klyde, B.J., Hirsch, J., 1979. Isotopic labeling of DNA in rat adipose tissue: evidence for proliferating cells associated with mature adipocytes. J. Lipid Res. 20, 691-704.

Kopp, A., Buechler, C., Neumeier, M., Weigert, J., Aslanidis, C., Schölmerich. J., Schäffler, A., 2009. Innate immunity and adipocyte function: ligand-specific activation of multiple Toll-like receptors modulates cytokine, adipokine, and chemokine secretion in adipocytes. Obesity (Silver Spring). 17, 648-656.

Kralisch, S., Klein, J., Lossner, U., Bluher, M., Paschke, R., Stumvoll, M., Fasshauer, M., 2005. Interleukin-6 is a negative regulator of visfatin gene expression in 3T3-L1 adipocytes. Am. J. Physiol. Endocrinol. Metab. 289, E586-E590.

Kraus, D., Fasshauer, M., Ott, V., Meier, B., Jost, M., Klein, H.H., Klein, J., 2002. Leptin secretion and negative autocrine crosstalk with insulin in brown adipocytes. J. Endocrinol. 175, 185-191. 
Kunduzova, O., Alet, N., Delesque-Touchard, N., Millet, L., Castan-Laurell, I., Muller, C., Dray, C., Schaeffer, P., Herault, J.P., Savi, P., Bono, F., Valet, P., 2008. Apelin/APJ signaling system: a potential link between adipose tissue and endothelial angiogenic processes. FASEB J. 22, 4146-4153.

Lagathu, C., Bastard, J.P., Auclair, M., Maachi, M., Capeau, J., Caron, M., 2003. Chronic interleukin-6 (IL-6) treatment increased IL-6 secretion and induced insulin resistance in adipocyte: prevention by rosiglitazone. Biochem. Biophys. Res. Commun. 311, 372-379.

Lefterova, M.,I., Lazar, M.,A., 2009. New developments in adipogenesis, Trends. Endocrinol. Metab. 20, 107-114.

Liang, X., Kanjanabuch, T., Mao, S.L., Hao, C.M., Tang, Y.W., Declerck, P.J., Hasty, A.H., Wasserman, D.H., Fogo, A.B., Ma, L.J., 2006. Plasminogen activator inhibitor-1 modulates adipocyte differentiation. Am. J. Physiol. Endocrinol. Metab. 290, E103-E113.

Lien C.C., Au L.C., Tsai Y.L., Ho L.T., Juan C.C., 2009. Short-term regulation of tumor necrosis factor-alpha-induced lipolysis in 3T3-L1 adipocytes is mediated through the inducible nitric oxide synthase/nitric oxide-dependent pathway. Endocrinology. 150, 4892-4900.

Lim J.Y., Kim W.H., Park S.I., 2008. GO6976 prevents TNF-alpha-induced suppression of adiponectin expression in 3T3-L1 adipocytes: putative involvement of protein kinase C. FEBS. Lett. 582, 3473-3478.

Lin, Y., Rajala, M.W., Berger, J.P., Moller, D.E., Barzilai, N., Scherer, P.E., 2001. Hyperglycemia-induced production of acute phase reactants in adipose tissue. J. Biol. Chem. 276, 42077-42083.

Lumeng, C.N., Bodzin, J.L., Saltiel, A.R., 2007. Obesity induces a phenotypic switch in adipose tissue macrophage polarization. J. Clin. Invest. 117, 175-184.

Madani, R., Karastergiou, K., Ogston, N.C., Miheisi, N., Bhome, R., Haloob, N., Tan, G. D., Karpe, F., Malone-Lee, J., Hashemi, M., Jahangiri, M., Mohamed-Ali, V., 2009. RANTES release by human adipose tissue in vivo and evidence for depot-specific differences. Am. J. Physiol Endocrinol. Metab. 296, E1262-E1268.

Maeda, K., Okubo, K., Shimomura, I., Funahashi, T., Matsuzawa, Y., Matsubara, K., 1996. cDNA cloning and expression of a novel adipose specific collagen-like factor, apM1 (AdiPose Most abundant Gene transcript 1). Biochem. Biophys. Res. Commun. 221, 286-289.

Maquoi, E., Munaut, C., Colige, A., Collen, D., Lijnen, H.R., 2002. Modulation of adipose tissue expression of murine matrix metalloproteinases and their tissue inhibitors with obesity. Diabetes. 51, 1093-1101. 
Massiéra, F., Bloch-Faure, M., Ceiler, D., Murakami, K., Fukamizu, A., Gasc, J.-M., Quignard-Boulangé, A., Negrel, R., Ailhaud, G., Seydoux, G., Meneton, P., Teboul M., 2001. Adipose angiotensinogen is involved in adipose tissue growth and blood pressure regulation. FASEB. J. 15, 2727-2729.

Maumus, M., Sengenès, C., Decaunes, P., Zakaroff-Girard, A., Bourlier, V., Lafontan, M., Galitzky, J., Bouloumié, A., 2008. Evidence of in situ proliferation of adult adipose tissue-derived progenitor cells: influence of fat mass microenvironment and growth. J. Clin. Endocrinol. Metab. 93, 4098-4106.

McTernan, P.G., Fisher, F.M., Valsamakis, G., Chetty, R., Harte, A., McTernan, C.L., Clark, P.M., Smith, S.A., Barnett, A.H., Kumar, S., 2003. Resistin and type 2 diabetes: regulation of resistin expression by insulin and rosiglitazone and the effects of recombinant resistin on lipid and glucose metabolism in human differentiated adipocytes. J. Clin. Endocrinol. Metab. 88, 6098-6106.

Mehebik N., Jaubert A.M., Sabourault D., Giudicelli Y., Ribière C., 2005. Leptininduced nitric oxide production in white adipocytes is mediated through PKA and MAP kinase activation. Am. J. Physiol. Cell. Physiol. 289, C379-C387.

Mick, G. J., Wang, X., McCormick, K., 2002. White adipocyte vascular endothelial growth factor: regulation by insulin. Endocrinology. 143, 948-953.

Mohamed-Ali, V., Goodrick, S., Bulmer, K., Holly, J.M., Yudkin, J.S., Coppack, S.W., 1999. Production of soluble tumor necrosis factor receptors by human subcutaneous adipose tissue in vivo. Am. J. Physiol. 277, E971-E975.

Mohamed-Ali, V., Goodrick, S., Rawesh, A., Katz, D.R., Miles, J.M., Yudkin, J.S., Klein, S., Coppack, S.W., 1997. Subcutaneous adipose tissue releases interleukin-6, but not tumor necrosis factor-alpha, in vivo. J. Clin. Endocrinol. Metab. 82, 4196-4200.

Murano, I., Barbatelli, G., Parisani, V., Latini, C., Muzzonigro, G., Castellucci, M., Cinti, S., 2008. Dead adipocytes, detected as crown-like structures, are prevalent in visceral fat depots of genetically obese mice. J. Lipid. Res. 49, 1562-1568.

Nannipieri, M., Bonotti, A., Anselmino, M., Cecchetti, F., Madec, S., Mancini, E., Baldi, S., Santini, F., Pinchera, A., Rossi, M., Ferrannini, E., 2007. Pattern of expression of adiponectin receptors in human adipose tissue depots and its relation to the metabolic state. Int. J. Obes (Lond). 31, 1842-1848.

Négrel R. 1999. Prostacyclin as a critical prostanoid in adipogenesis. Prostaglandins. Leukot. Essent. Fatty. Acids. 60, 383-386.

Nisoli, E., Clementi, E., Paolucci, C., Cozzi, V., Tonello, C., Sciorati, C., Bracale, R., Valerio, A., Francolini, M., Moncada, S., Carruba, M.O., 2003. Mitochondrial biogenesis in mammals: the role of endogenous nitric oxide. Science. 299, 896-899. 
Nisoli, E., Falcone, S., Tonello, C., Cozzi, V., Palomba, L., Fiorani, M., Pisconti, A, Brunelli, S., Cardile, A., Francolini, M., Cantoni, O., Carruba, M.O., Moncada, S., Clementi, E., 2004. Mitochondrial biogenesis by NO yields functionally active mitochondria in mammals. Proc. Natl. Acad. Sci. U. S. A. 101, 16507-16512.

Ogston, N.C., Karastergiou, K., Hosseinzadeh-Attar, M.J., Bhome, R., Madani, R., Stables, M., Gilroy, D., Flachs, P., Hensler, M., Kopecky, J., Mohamed-Ali, V., 2008. Low-dose acetylsalicylic acid inhibits the secretion of interleukin-6 from white adipose tissue. Int. J. Obes. (Lond). 32, 1807-1815.

Ouchi, N., Kihara, S., Funahashi, T., Nakamura, T., Nishida, M., Kumada, M., Okamoto, Y., Ohashi, K., Nagaretani, H., Kishida, K., Nishizawa, H., Maeda, N., Kobayashi, H., Hiraoka, H., Matsuzawa, Y., 2003. Reciprocal association of C-reactive protein with adiponectin in blood stream and adipose tissue. Circulation. 107, 671-674.

Ouchi, N., Kobayashi, H., Kihara, S., Kumada, M., Sato, K., Inoue, T., Funahashi, T., Walsh, K., 2004. Adiponectin stimulates angiogenesis by promoting cross-talk between AMP-activated protein kinase and Akt signaling in endothelial cells. J. Biol. Chem. 279, 1304-1309.

Pandey M., Loskutoff D.J., Samad F., 2005. Molecular mechanisms of tumor necrosis factor-alpha-mediated plasminogen activator inhibitor-1 expression in adipocytes. FASEB. J. 19, 1317-1319.

Päth, G., Bornstein, S.R., Gurniak, M., Chrousos, G.P., Scherbaum, W.A., Hauner, H., 2001. Human breast adipocytes express interleukin-6 (IL-6) and its receptor system: increased IL-6 production by beta-adrenergic activation and effects of IL-6 on adipocyte function. J. Clin. Endocrinol. Metab. 86, 2281-2288.

Peeraully, M.R., Jenkins, J.R., Trayhurn, P., 2004. NGF gene expression and secretion in white adipose tissue: regulation in 3T3-L1 adipocytes by hormones and inflammatory cytokines. Am. J. Physiol. Endocrinol. Metab. 287, E331-E339.

Pérez, C., Fernández-Galaz, C., Fernández-Agulló, T., Arribas, C., Andrés, A., Ros, M., Carrascosa, J.M., 2004. Leptin impairs insulin signaling in rat adipocytes. Diabetes. 53, 347-353.

Petersen, E.W., Carey, A.L., Sacchetti, M., Steinberg, G.R., Macaulay, S.L., Febbraio, M.A., Pedersen, B.K., 2005. Acute IL-6 treatment increases fatty acid turnover in elderly humans in vivo and in tissue culture in vitro. Am. J. Physiol. Endocrinol. Metab. 288, E155-E162.

Pravenec, M., Kazdová, L., Cahová, M., Landa, V., Zídek, V., Mlejnek, P., Simáková, M., Wang, J., Qi, N., Kurtz, T.W., 2006. Fat-specific transgenic expression of resistin in the spontaneously hypertensive rat impairs fatty acid re-esterification. Int. J. Obes (Lond). 30, 1157-1159. 
Rasmussen, M.S., Lihn, A.S., Pedersen, S.B., Bruun, J.M., Rasmussen, M., Richelsen, B., 2006. Adiponectin receptors in human adipose tissue: effects of obesity, weight loss, and fat depots. Obesity (Silver Spring). 14, 28-35.

Rega, G., Kaun, C., Weiss, T.W., Demyanets, S., Zorn, G., Kastl, S.P., Steiner, S., Seidinger, D., Kopp, C.W., Frey, M., Roehle, R., Maurer, G., Huber, K., Wojta, J., 2005. Inflammatory cytokines interleukin-6 and oncostatin $\mathrm{m}$ induce plasminogen activator inhibitor-1 in human adipose tissue. Circulation. 111, 1938-1945.

Rega, G., Kaun, C., Demyanets, S., Pfaffenberger, S., Rychli, K., Hohensinner, P.J., Kastl, S.P., Speidl, W.S., Weiss, T.W., Breuss, J.M., Furnkranz, A., Uhrin, P., Zaujec, J., Zilberfarb, V., Frey, M., Roehle, R., Maurer, G., Huber, K., Wojta, J., 2007. Vascular endothelial growth factor is induced by the inflammatory cytokines interleukin- 6 and oncostatin $\mathrm{m}$ in human adipose tissue in vitro and in murine adipose tissue in vivo. Arterioscler. Thromb. Vasc. Biol. 27, 1587-1595.

Rhee S.D., Sung Y.Y., Jung W.H., Cheon H.G., 2008. Leptin inhibits rosiglitazoneinduced adipogenesis in murine primary adipocytes. Mol. Cell. Endocrinol. 294, 61-69.

Richelsen, B., 1992. Release and effects of prostaglandins in adipose tissue. Prostaglandins Leukot Essent Fatty Acids. 47, 171-82.

Ritchie, S.A., Ewart, M.A., Perry, C.G., Connell, J.M., Salt, I.P., 2004. The role of insulin and the adipocytokines in regulation of vascular endothelial function. Clin Sci (Lond). 107, 519-532.

Roh, S., Song, S.-H., Choi, K.-C., Katoh, K., Wittamer, V., Parmentier, M., Sasaki, S., 2007. Chemerin - A new adipokine that modulates adipogenesis via its own receptor. Biochem. Biophys. Res. Commun. 362, 1013-1018.

Rosen, E.D., and Spiegelman, B.M., 2006. Adipocytes as regulators of energy balance and glucose homeostasis, Nature. 444, 847-853.

Rotter, V., Nagaev, I., Smith, U., 2003. Interleukin-6 (IL-6) induces insulin resistance in 3T3-L1 adipocytes and is, like IL-8 and tumor necrosis factor-alpha, overexpressed in human fat cells from insulin-resistant subjects. J. Biol. Chem. 278, 45777-45784.

Ruan H., Hacohen N., Golub T.R., Van Parijs L., Lodish H.F., 2002. Tumor necrosis factor-alpha suppresses adipocyte-specific genes and activates expression of preadipocyte genes in 3T3-L1 adipocytes: nuclear factor-kappaB activation by TNF-alpha is obligatory. Diabetes. 51, 1319-1336.

Rydén, M., Arner, P., 2007. Tumour necrosis factor- $\alpha$ in human adipose tissue - from signalling mechanisms to clinical implications. J. Intern. Med. 262, 431-438. 
Ryden, M., Elizalde, M., van Harmelen, V., Ohlund, A., Hoffstedt, J., Bringman, S., Andersson, K., 2001. Increased expression of eNOS protein in omental versus subcutaneous adipose tissue in obese human subjects. Int. J. Obes. Relat. Metab. Disord. 25, 811-815.

Saleh, J., Summers, L.K., Cianflone, K., Fielding, B.A., Sniderman, A.D., Frayn, K.N., 1998. Coordinated release of acylation stimulating protein (ASP) and triacylglycerol clearance by human adipose tissue in vivo in the postprandial period. J. Lipid. Res. 39, 884-891.

Samad F., Yamamoto K., Pandey M., Loskutoff D.J., 1997. Elevated expression of transforming growth factor-beta in adipose tissue from obese mice. Mol. Med. 3, 37-48.

Schaffler, A., Neumeier, M., Herfarth, H., Furst, A., Scholmerich, J. Buchler, C., 2005. Genomic structure of human omentin, a new adipocytokine expressed in omental adipose tissue. Biochim. Biophys. Acta. 1732, 96-102.

Schaffler, A., Furst, A., Buchler, C., Paul, G., Rogler, G., Scholmerich, J., Herfarth, H., 2006. Secretion of RANTES (CCL5) and interleukin-10 from mesenteric adipose tissue and from creeping fat in Crohn's disease: regulation by steroid treatment. J. Gastroenterol. Hepatol. 21, 1412-1418.

Scherer, P.E., Williams, S., Fogliano, M., Baldini, G., Lodish, H.F., 1995. A novel serum protein similar to C1q, produced exclusively in adipocytes. J. Biol. Chem. 270, 2674626749.

Sell, H., Dietze-Schroeder, D., Eckardt, K., Eckel, J., 2006. Cytokine secretion by human adipocytes is differentially regulated by adiponectin, AICAR, and troglitazone. Biochem. Biophys. Res. Commun. 343, 700-706.

Shaw, J. E., Ramwell, P.W., 1968. Release of prostaglandin from rat epididymal fat pad on nervous and hormonal stimulation. J. Biol. Chem. 243, 1498-1503.

Shibata, R., Ouchi, N., Kihara, S., Sato, K., Funahashi, T., Walsh, K., 2004. Adiponectin stimulates angiogenesis in response to tissue ischemia through stimulation of ampactivated protein kinase signaling. J. Biol. Chem. 279, 28670-28674.

Sierra-Honigmann, M.R., Nath, A.K., Murakami, C., García-Cardeña, G., Papapetropoulos, A., Sessa, W.C., Madge, L.A., Schechner, J.S., Schwabb, M,B., Polverini, P.J., Flores-Riveros, J.R., 1998. Biological action of leptin as an angiogenic factor. Science. 281, 1683-1686.

Simons, P.J., van den Pangaart, P.S., Aerts, J.M., Boon, L., 2007. Pro-inflammatory delipidizing cytokines reduce adiponectin secretion from human adipocytes without affecting adiponectin oligomerization. J. Endocrinol. 192, 289-299. 
Smith, S.R., Ravussin, E., 2006. Role of adipocyte in metabolism and endocrine function. In: D.A. Jameson, Editor, Endocrinology, Elsevier Saunders. 1045-1062.

Smith, S.R., Lovejoy, J.C., Greenway, F., Ryan, D., deJonge, L., de la Bretonne, J., Volafova, J., Bray, G.A., 2001. Contributions of total body fat, abdominal subcutaneous adipose tissue compartments, and visceral adipose tissue to the metabolic complications of obesity. Metabolism. 50, 425-435.

Sopasakis, V.R., Sandqvist, M., Gustafson, B., Hammarstedt, A., Schmelz, M., Yang, X., Jansson, P.A., Smith, U., 2004. High local concentrations and effects on differentiation implicate interleukin-6 as a paracrine regulator. Obes. Res. 12, 454-460.

Spalding, K.L., Arner, E., Westermark, P.O., Bernard, S., Buchholz, B.A., Bergmann, O., Blomqvist, L., Hoffstedt, J., Näslund, E., Britton, T., Concha, H., Hassan, M., Rydén, M., Frisén, J., Arner, P., 2008. Dynamics of fat cell turnover in humans. Nature. 453, 783787.

Spoto, B., Parlongo, R.M., Parlongo, G., Sgro', E., Zoccali, C., 2007. The enzymatic machinery for ADMA synthesis and degradation is fully expressed in human adipocytes. J. Nephrol. 20, 554-559.

Steppan, C.M., Bailey, S.T., Bhat, S., Brown, E.J., Banerjee, R.R., Wright, C.M., Patel, H.R., Ahima, R.S., Lazar, M.A., 2001. The hormone resistin links obesity to diabetes. Nature. 409, 307-312.

Steppan C.M., Wang J., Whiteman E.L., Birnbaum M.J., Lazar M.A., 2005. Activation of SOCS-3 by resistin. Mol. Cell. Biol. 25, 1569-1575.

Strissel, K.J., Stancheva, Z., Miyoshi, H., Perfield, J.W. 2nd, DeFuria, J., Jick, Z., Greenberg, A.S., Obin, M.S., 2007. Adipocyte death, adipose tissue remodeling, and obesity complications. Diabetes. 56, 2910-2918.

Stouthard, J.M., Oude Elferink, R.P., Sauerwein, H.P., 1996. Interleukin-6 enhances glucose transport in 3T3-L1 adipocytes. Biochem. Biophys. Res. Commun. 220, 241-245.

Strawford, A., Antelo, F., Christiansen, M., Hellerstein, M.K., 2004. Adipose tissue triglyceride turnover, de novo lipogenesis, and cell proliferation in humans measured with 2H2O. Am. J. Physiol. Endocrinol. Metab. 286, E577-E588.

Suzawa M., Takada I., Yanagisawa J., Ohtake F., Ogawa S., Yamauchi T., Kadowaki T., Takeuchi Y., Shibuya H., Gotoh Y., Matsumoto K., Kato S., 2003. Cytokines suppress adipogenesis and PPAR-gamma function through the TAK1/TAB1/NIK cascade. Nat. Cell. Biol. 5, 224-230.

Takahashi, M., Takahashi, Y., Takahashi, K., Zolotaryov, F.N., Hong, K.S., Kitazawa, R., Iida, K., Okimura, Y., Kaji, H., Kitazawa, S., Kasuga, M., Chihara, K., 2008. 
Chemerin, a novel adipokine that regulates adipogenesis and adipocyte metabolism. FEBS. Lett. 282, 573-578.

Tan, B.K., Chen, J., Brown, J., Adya, R., Ramanjaneya, M., Menon, V., Bailey, C.J., Lehnert, H., Randeva, H.S., 2009. In Vivo and Ex Vivo Regulation of Visfatin Production by Leptin in Human and Murine Adipose Tissue: Role of MAPK and PI3-K Signalling Pathways. Endocrinology. [Epub ahead of print].

Tanaka, T., Itoh, H., Doi, K., Fukunaga, Y., Hosoda, K., Shintani, M., Yamashita, J., Chun, T.H., Inoue, M., Masatsugu, K., Sawada, N., Saito, T., Inoue, G., Nishimura, H., Yoshimasa, Y., Nakao, K., 1999. Down regulation of peroxisome proliferator-activated receptorgamma expression by inflammatory cytokines and its reversal by thiazolidinediones. Diabetologia. 42, 702-710.

Tanaka, T., Nakatani, K., Morioka, K., Urakawa, H., Maruyama, N., Kitagawa, N., Katsuki, A., Araki-Sasaki, R., Hori, Y., Gabazza, E.C., Yano, Y., Wada, H., Nobori, T., Sumida, Y., Adachi, Y., 2003. Nitric oxide stimulates glucose transport through insulinindependent GLUT4 translocation in 3T3-L1 adipocytes. Eur. J. Endocrinol. 149, 61-67.

Tomono, Y., Iwai, M., Inaba, S., Mogi, M., Horiuchi, M., 2008. Blockade of AT1 receptor improves adipocyte differentiation in atherosclerotic and diabetic models. Am. J. Hypert. 21, 206-212.

Trayhurn, P., 2005. Endocrine and signalling role of adipose tissue: new perspectives on fat. Acta. Physiol. Scand. 184, 285-293.

Trayhurn, P., Wang, B., Wood, I.S., 2008. Hypoxia in adipose tissue: a basis for the dysregulation of tissue function in obesity?. Br. J. Nutr. 100, 227-235.

Trujillo, M.E., Lee, M.J., Sullivan, S., Feng, J., Schneider, S.H., Greenberg, A.S., Fried, S.K., 2006. Tumor necrosis factor alpha and glucocorticoid synergistically increase leptin production in human adipose tissue: role for p38 mitogen-activated protein kinase. J. Clin. Endocrinol. Metab. 91, 1484-1490.

Vallance P., Leiper J., 2002. Blocking NO synthesis: how, where and why? Nat. Rev. Drug. Discov. 12, 939-950.

Vassaux, G., Gaillard, D., Darimont, C., Ailhaud, G., Negrel, R., 1992. Differential response of preadipocytes and adipocytes to prostacyclin and prostaglandin E2: physiological implications. Endocrinology. 131, 2393-2398.

Vona-Davis, L., Rose, D.P., 2009. Angiogenesis, adipokines and breast cancer. Cytokine. Growth. Factor. Rev. 20, 193-201.

Wajchenberg,B.L., 2000. Subcutaneous and visceral adipose tissue: their relation to the metabolic syndrome. Endocr. Rev. 21, 697-738. 
Wang, B., Jenkins, J.R., Trayhurn, P., 2005. Expression and secretion of inflammationrelated adipokines by human adipocytes differentiated in culture: integrated response to TNF-alpha. Am. J. Physiol. Endocrinol. Metab. 288, E731-E740.

Wang, M., Orci, L., Ravazzola, M., Unger, R.H., 2005. Fat storage in adipocytes requires inactivation of leptin's paracrine activity: implications for treatment of human obesity. Proc. Natl. Acad. Sci. U S A. 102, 18011-18016.

Wang, M.Y., Grayburn, P., Chen, S., Ravazzola, M., Orci, L., Unger, R.H., 2008. Adipogenic capacity and the susceptibility to type 2 diabetes and metabolic syndrome. Proc. Natl. Acad. Sci. U S A. 105, 6139-6144.

Weisberg, S.P., McCann, D., Desai, M., Rosenbaum, M., Leibel, R.L., Ferrante, A.W. Jr., 2003. Obesity is associated with macrophage accumulation in adipose tissue. J. Clin. Invest. 112, 1796-1808.

Weyer, C., Foley, J.E., Bogardus, C., Tataranni, P.A., Pratley, R,E., 2000. Enlarged subcutaneous abdominal adipocyte size, but not obesity, predicts type II diabetes independent of insulin resistance. Diabetologia. 43, 1498-1506.

Yang, R.Z., Lee, M.J., Hu, H., Pray, J., Wu, H.B., Hansen, B.C., Shuldiner, A.R., Fried, S.K., McLenithan, J.C., Gong, D.W., 2006. Identification of omentin as a novel depotspecific adipokine in human adipose tissue: possible role in modulating insulin action. Am. J. Physiol. Endocrinol. Metab. 290, E1253-61.

Yang Y., Ju D., Zhang M., Yang G., 2008. Interleukin-6 stimulates lipolysis in porcine adipocytes. Endocrine. 33, 261-269.

Yokota, T., Meka, C.S., Medina, K.L., Igarashi, H., Comp, P.C., Takahashi, M., Nishida, M., Oritani, K., Miyagawa, J., Funahashi, T., Tomiyama, Y., Matsuzawa, Y., Kincade, P.W., 2002. Paracrine regulation of fat cell formation in bone marrow cultures via adiponectin and prostaglandins. J. Clin. Invest. 109, 1303-1310.

Zhang, H.H., Kumar, S., Barnett, A.H., Eggo, M.C., 1999. Intrinsic Site-Specific Differences in the Expression of Leptin in Human Adipocytes and Its Autocrine Effects on Glucose Uptake. J. Clin. Endocrinol. Metab. 84, 2550-2556.

Zhang H.H., Halbleib M., Ahmad F., Manganiello V.C., Greenberg A.S., 2002. Tumor necrosis factor-alpha stimulates lipolysis in differentiated human adipocytes through activation of extracellular signal-related kinase and elevation of intracellular cAMP. Diabetes. 51, 2929-2935.

Zhang J., Gao Z., Yin J., Quon M.J., Ye J., 2008. S6K directly phosphorylates IRS-1 on Ser-270 to promote insulin resistance in response to TNF-(alpha) signaling through IKK2. J. Biol. Chem. 283, 35375-35382. 
Zhang, Y., Olbort, M., Schwarzer, K., Nuesslein-Hildesheim, B., Nicolson, M., Murphy, E., Kowalski, T.J., Schmidt, I., Leibel, R.L., 1997. The Leptin Receptor Mediates Apparent Autocrine Regulation of Leptin Gene Expression. Biochem. Biophys. Res. Commun. 240, 492-495.

Zhang, Y., Proenca, R., Maffei, M., Barone, M., Leopold, L., Friedman, J.M., 1994. Positional cloning of the mouse obese gene and its human homologue. Nature. 372, 425432.

Zhang, Z., Schluesener, H.J., 2006. Mammalian toll-like receptors: from endogenous ligands to tissue regeneration. Cell Mol Life Sci. 63, 2901-7.

Zovich, D.C., Orologa, A., Okuno, M., Kong, L.W., Talmage, D.A., Piantedosi, R., Goodman, D.S., Blaner, W.S., 1992. Differentiation-dependent expression of retinoidbinding proteins in BFC-1 beta adipocytes. J. Biol. Chem. 267, 13884-13889. 
Table 1: Signals derived from adipose tissue

\begin{tabular}{|c|c|c|}
\hline Immune characteristics & Adipokine & References \\
\hline \multirow[t]{6}{*}{ Cytokine-like molecules } & Leptin & $\begin{array}{l}\text { Klein et al., 1996; Zhang et } \\
\text { al., } 1994\end{array}$ \\
\hline & IL-6/IL-6sR & Mohamed-Ali et al., 1997 \\
\hline & TNF $\alpha /$ TNFsR1/TNFsR2 & $\begin{array}{l}\text { Hotamisligil et al., 1993; } \\
\text { Mohamed-Ali et al., } 1999\end{array}$ \\
\hline & IL-8 & Bruun et al., 2001 \\
\hline & IL-10 & Juge-Aubry et al., 2005 \\
\hline & MIF & Hirokawa et al., 1997 \\
\hline \multirow{3}{*}{ Complement-like factors } & Adipsin & Cook et al., 1987 \\
\hline & ASP & Cianflone et al., 1989 \\
\hline & Adiponectin & $\begin{array}{l}\text { Hu et al., 1996; Maeda et } \\
\text { al., 1996; Scherer et al., } \\
1995\end{array}$ \\
\hline \multirow[t]{4}{*}{ Chemokines } & MCP-1 & Gerhardt et al., 2001 \\
\hline & RANTES & $\begin{array}{l}\text { Madani et al., 2009; } \\
\text { Schaffler et al., 2006 }\end{array}$ \\
\hline & MIP-1 $1 \alpha$ & Gerhardt et al., 2001 \\
\hline & Chemerin & Goralski et al., 2007 \\
\hline \multirow[t]{4}{*}{ Acute phase proteins } & Serum Amyloid A & $\begin{array}{l}\text { Benditt \& Meek, 1989; Lin } \\
\text { et al., } 2001\end{array}$ \\
\hline & C-Reactive Protein & Ouchi et al., 2003 \\
\hline & Haptoglobin & Friedrichs et al., 1995 \\
\hline & PAI-1 & Alessi et al., 1997 \\
\hline \multirow[t]{5}{*}{ Growth factors } & HGF & Fain et al., 2004 \\
\hline & NGF & Peeraully et al., 2004 \\
\hline & TGF $\beta$ & Samad et al., 1997 \\
\hline & VEGF & $\begin{array}{l}\text { Claffey et al., 1992; Mick } \\
\text { et al., } 2002\end{array}$ \\
\hline & Visfatin & Fukuhara et al., 2002 \\
\hline \multirow[t]{2}{*}{ Adhesion molecules } & VCAM-1 & Fain et al., 2007 \\
\hline & ICAM-1 & Brake et al., 2006 \\
\hline Enzymatic pathways & $\begin{array}{l}\text { Components of the COX } \\
\text { pathway: PGI2, PGE2 }\end{array}$ & $\begin{array}{l}\text { Ogston et al., 2008; Shaw } \\
\text { \& Ramwell, } 1968\end{array}$ \\
\hline \multirow[t]{3}{*}{ 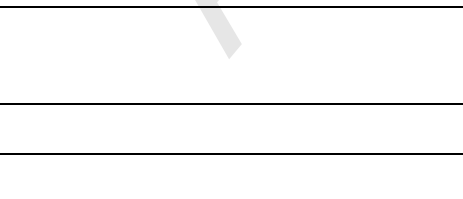 } & $\begin{array}{l}\text { Components of the NO } \\
\text { pathway: NO, ADMA }\end{array}$ & Spoto et al., 2007 \\
\hline & RAS & Frederich et al., 1992 \\
\hline & MMPs/TIMPs & Maquoi et al., 2002 \\
\hline \multirow[t]{5}{*}{ Others } & Apelin & Boucher et al., 2005 \\
\hline & RBP4 & Zovish et al., 1992 \\
\hline & Resistin & Steppan et al., 2001 \\
\hline & Omentin & Schaffler et al., 2005 \\
\hline & Vaspin & Hida et al., 2005 \\
\hline
\end{tabular}


IL: interleukin; TNF: tumour necrosis factor; MIF: macrophage migration inhibitory factor; MCP: macrophage chemotactic protein; RANTES: regulated upon activation, normally $\mathrm{T}$ cell expressed and secreted; MIP: macrophage inhibitory protein; PAI: plasminogen activator inhibitor; HGF: hepatocyte growth factor; NGF: nerve growth factor; VEGF: vascular endothelial growth factor; VCAM: vascular cell adhesion molecule; ICAM-1: intracellular adhesion molecule; COX: cyclo-oxygenase; NO: nitric oxide; ADMA: asymmetric dimethylarginine; RAS: renin angiotensin system; MMP: matrix metalloproteinase; TIMP: tissue inhibitor of metalloproteinases; RBP: retinol binding protein. 
Table 2. Signaling pathways activated by adipokines in adipocytes

\begin{tabular}{|c|c|c|c|c|}
\hline \multicolumn{2}{|c|}{ Adipokine / Function } & Signaling pathway & Cell type & Effect \\
\hline \multicolumn{2}{|c|}{ Adiponectin: Adipogenesis } & - COX2/PGE2 & - Human bone marrow brown preadipocytes & - ( $\downarrow) \mathrm{CEBP} \alpha / \mathrm{PPAR} \gamma$ \\
\hline & $\begin{array}{l}\text { Secretory } \\
\text { Functions }\end{array}$ & - PPAR $\gamma / \mathrm{NF}-\kappa \mathrm{B}(\downarrow)$ & - 3T3L1/Porcine adipocytes (Ajuwon et al., 2005) & $\bullet(\downarrow)$ IL-6/ TNF $\alpha$ \\
\hline \multirow[t]{4}{*}{ IL-6: } & Adipogenesis & - Dv1/ $\beta$-catenin & • 3T3L1 (Gustafson et al., 2006) & - $(\downarrow) \mathrm{CEBP} \alpha$ \\
\hline & $\begin{array}{l}\text { Metabolic } \\
\text { Functions }\end{array}$ & - ERK & - Porcine adipocytes (Yang et al., 2008) & - $(\downarrow)$ perilipin \\
\hline & $\begin{array}{l}\text { Secretory } \\
\text { Functions }\end{array}$ & • MAPK & $\begin{array}{l}\text { - 3T3L1 (Fasshauer et al., 2003, Kralisch et al., } \\
\text { 2005) }\end{array}$ & - $(\downarrow)$ adiponectin/ visfatin \\
\hline & & - MAPK-JAK2 & - 3T3L1 (Fasshauer et al., 2004) & - $(\uparrow) \mathrm{MCP}-1$ \\
\hline \multirow[t]{3}{*}{ Leptin: } & Adipogenesis & - ERK-STAT1 & - Murine preadipocytes (Rhee et al., 2008) & - $(\downarrow) \operatorname{PPAR} \gamma$ \\
\hline & $\begin{array}{l}\text { Metabolic } \\
\text { Functions }\end{array}$ & - MAPK-STAT3 & - Murine brown adipocytes (Kraus et al., 2002) & - $(\downarrow)$ IR kinase activity \\
\hline & $\begin{array}{l}\text { Secretory } \\
\text { Functions }\end{array}$ & - MAPK-PKA & - Murine adipocytes (Mehebik et al., 2005) & - Activation of NOS \\
\hline Resistin: & $\begin{array}{l}\text { Metabolic } \\
\text { Functions }\end{array}$ & $\begin{array}{l}\text { - SOCS3 } \\
\text { - PKB/AMPK }\end{array}$ & $\begin{array}{l}\text { - 3T3-L1 (Steppan et al., 2005) } \\
\text { - 3T3-L1 (Kim et al., 2007) }\end{array}$ & $\begin{array}{l}-(\downarrow) \text { tyrosine phosphorylation of IR } \\
\bullet(\uparrow) \text { LPL activity }\end{array}$ \\
\hline TGF $\beta$ : & Adipogenesis & - $\mathrm{Smad} 3 / 4$ & - 3T3L1 (Choy et al., 2003) & - $(\downarrow) \mathrm{CEBP} \beta / \delta$ activity \\
\hline
\end{tabular}




\begin{tabular}{|c|c|c|c|c|}
\hline TNFa: & $\begin{array}{l}\text { Secretory } \\
\text { Functions }\end{array}$ & 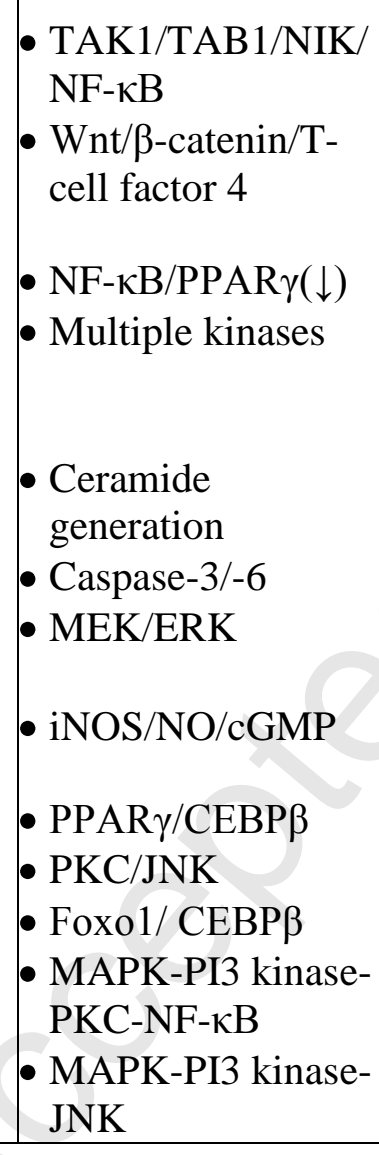 & $\begin{array}{l}\text { - Mouse bone marrow stromal cells (Suzawa et al., } \\
\text { - } 3003 \text { ) } \\
\text { preadipocytes (Isakson et al., 2009) } \\
\text { - 3T3-L1 (Iwata et al., 2001, Ruan et al., 2002) } \\
\text { - 3T3-L1 (Engelman et al., 2000, Gao et al., 2003, } \\
\text { Zhang et al., 2008), human visceral adipocytes } \\
\text { (Fernandez-Veledo et al., 2009) } \\
\text { - Rat brown adipocytes (Teruel et al., 2001) } \\
\text { - 3T3-L1 (Guilherme et al., 2009) } \\
\text { - Human adipocytes (Zhang et al., 2002) } \\
\text { - 3T3-L1 (Lien et al., 2009) } \\
\text { - 3T3-L1 (Ruan et al., 2002, Kita et al., 2005) } \\
\text { - 3T3-L1 (Kim et al., 2005, Lim et al., 2008) } \\
\text { - 3T3-L1 (Ito et al., 2009) } \\
\text { - 3T3-L1 (Pandey et al., 2005) } \\
\text { - 3T3-F442A (Daviaud et al., 2006) }\end{array}$ & $\begin{array}{l}\text { - }(\downarrow) \text { PPAR } \gamma \text { activity } \\
\text { - }(\downarrow) \text { PPAR } \gamma / \text { CEBP } \alpha \\
\text { - }(\downarrow) \text { GLUT-4/IR/IRS-1/Akt protein } \\
\text { - Serine phosphorylation of IRS-1 } \\
\text { - }(\downarrow) \text { GLUT-4 translocation } \\
\text { - }(\downarrow) \text { PPAR } \gamma \text { protein } \\
\text { ( }() \text { intracellular cAMP and } \\
\text { perilipin phosphorylation } \\
\text { - HSL phosphorylation } \\
\text { - }(\downarrow) \text { adiponectin } \\
\text { - }(\downarrow) \text { adiponectin } \\
\bullet(\uparrow) \text { MCP-1/ IL-6 } \\
\bullet(\uparrow) \text { PAI-1 } \\
\bullet(\downarrow) \text { apelin }\end{array}$ \\
\hline
\end{tabular}

3T3-L1 and 3T3-F442A refers only to preadipocytes or adipocytes in this Table. AMPK: AMP-activated kinase; CEBP: CCAAT enhancer-binding protein; COX: cyclooxygenase; Dvl: dishevelled; ERK: extracellular signal related kinase; GLUT: glucose transporter; HSL: hormone sensitive lipase; IL: interleukin; IR: insulin receptor; IRS: insulin receptor substrate; JAK: Janus tyrosine kinase; JNK: c-Jun- $\mathrm{NH}_{2}$-terminal kinase; LPL: lipoprotein lipase; MAPK: mitogen activated protein kinase; MCP: monocyte chemoattractant protein; MEK: mitogen-activated protein kinase kinase; NF- $\kappa$ B: nuclear factor- $\kappa \mathrm{B}$; NIK: NF- $\kappa \mathrm{B}-\mathrm{inducing}$ kinase; NOS: nitric oxide synthase; PAI: plasminogen activator inhibitor; PK: protein kinase; PG: prostaglandin; PI: phosphatidylinositol; 
PPAR: peroxisome proliferator activated receptor; STAT: signal transducer and activator of transcription; TGF: transforming growth factor; TNF: tumour necrosis factor. 


\section{Figure legends}

\section{Figure 1.}

The figure shows a schematic representation of the alterations in adipose tissue that accompany body weight gain. In the lean state the tissue secretes elevated levels of adiponectin and other anti-inflammatory adipokines and is insulin responsive. Increased energy intake is followed by adipocyte hypertrophy/death and chemotactic adipokine release (eg MCP-1). This facilitates macrophage infiltration into the tissue and exacerbates the inflammatory response. These secretory changes are accompanied by local insulin resistance and hypoxia. Many of the adipokines released by this inflamed adipose tissue cause insulin resistance and endothelial dysfunction, precursors to many metabolic diseases.

\footnotetext{
Dead adipocyte
} 


\section{Lean / healthy state}

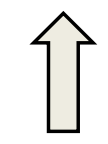

个Insulin sensitivity

Normal endothelial function

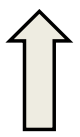

$\uparrow$ Anti-inflammatory adipokines

$\downarrow$ Pro-inflammatory adipokines
Adipose tissue expansion / inflammation

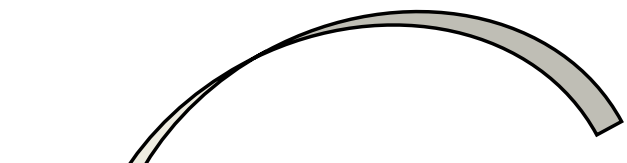

$\downarrow$ Adiponectin, omentin

个TNFa, IL-6, IL-8, MIF, MCP-1, RANTES

个leptin, adipsin, chemerin, visfatin, apelin, vaspin

个SAA, haptoglobin, PAI-1

个HGF, NGF, TGF $\beta$, VEGF

Activation of COX, NOS, RAS and MMPs
Obesity-associated pathologies

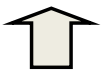

$\downarrow$ Insulin sensitivity

Endothelial dysfunction

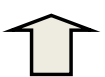

$\downarrow$ Anti-inflammatory adipokines

$\uparrow \uparrow$ Pro-inflammatory adipokines
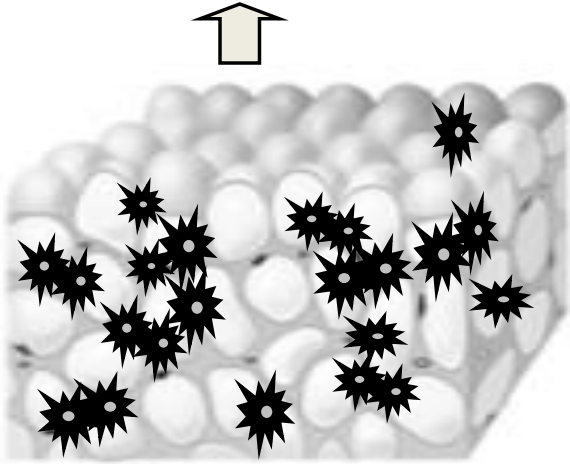